\title{
The operation, products and promotion of waterpipe businesses in New York City, Abu Dhabi and Dubai
}

P.J. Joudrey, ${ }^{7}$ K.A. Jasie, ${ }^{1}$ L. Pykalo, ${ }^{7}$ S.T. Singer, ${ }^{1}$ M.B. Woodin, ${ }^{7}$ and S. Sherman ${ }^{1-3}$

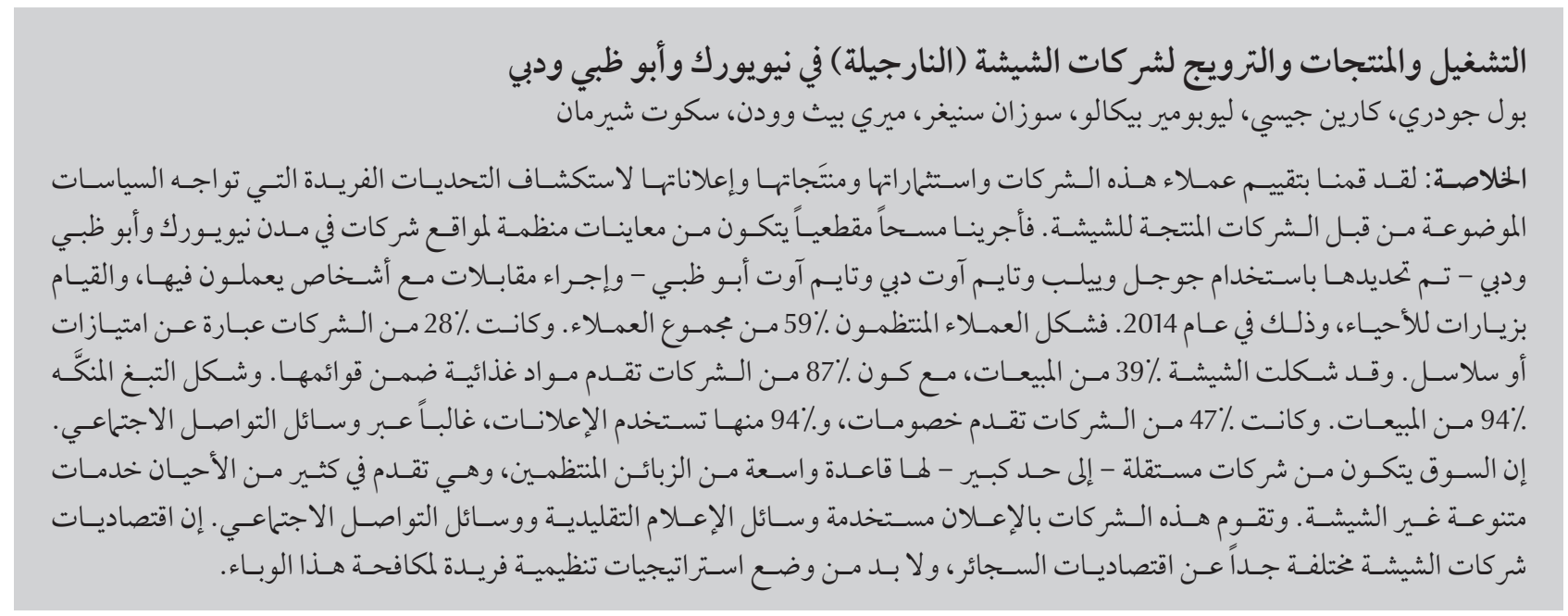

ABSTRACT We evaluated the customers, operations, products and advertising of these businesses to explore the unique policy challenges created by the suppliers of waterpipes. We completed a cross-sectional survey consisting of structured site observations and in-person interviews of businesses in New York City, Abu Dhabi and Dubai identified using Google, Yelp, Timeout Dubai and Timeout Abu Dhabi and neighbourhood visits in 2014. Regular customers made up 59\% of customers. Franchises or chains were 28\% of businesses. Waterpipes made up 39\% of sales with $87 \%$ of businesses offering food within their menu. Flavoured tobacco made up 94\% of sales. Discounts were offered by $47 \%$ of businesses and $94 \%$ of businesses used advertising, often through social media. The market consists of largely independent businesses, with a large regular customer base, frequently offering diversified services beyond waterpipes. These businesses advertise using both traditional and social media. The economics of waterpipe businesses is very different from the economics of cigarettes, and unique regulatory strategies are needed to control this epidemic.

Fonctionnement, produits et moyens de promotion des établissements proposant du tabac à narguilé à New York, Abu Dhabi et Dubaï

RÉSUMÉ Nous avons étudié les clients, les modes de fonctionnement, les produits et les types de publicité de ces commerces afin d'examiner les défis réglementaires spécifiques posés par les fournisseurs de narguilés. Nous avons mené une étude transversale composée d'observations sur site et d'entretiens structurés de visu dans des commerces situés à New York, Abu Dhabi et Dubaï, identifiés au moyen de recherches sur Google, Yelp, Timeout Dubai et Timeout Abu Dhabi, et de visites de voisinage en 2014. Les clients réguliers constituaient $59 \%$ du nombre total de clients. Les franchises et les chaînes comptaient pour 28 \% des commerces. Les narguilés représentaient $39 \%$ des ventes, $87 \%$ des commerces proposant de la nourriture au menu. Le tabac aromatisé constituait $94 \%$ des ventes. Des réductions étaient proposées par $47 \%$ des commerces et $94 \%$ d'entre eux avaient recours à la publicité, le plus souvent via les médias sociaux. Le marché est majoritairement composé de commerces indépendants, disposant d'une clientèle importante et régulière, et offrant souvent des services diversifiés en plus des narguilés. Ces commerces font de la publicité en recourant aux moyens traditionnels ainsi que via les médias sociaux. Le marché de ce type d'établissements diffère grandement de celui des cigarettes ; il est donc nécessaire de mettre au point des stratégies de réglementation spécifiques pour enrayer cette épidémie.

${ }^{7}$ NYU College of Global Public Health, New York, New York, United States of America (Correspondence to: paul.joudrey@gmail.com). ${ }^{2}$ Department of Population Health, NYU School of Medicine, New York, New York, United States of America. ${ }^{3}$ NYU Abu Dhabi Public Health Research Center, Abu Dhabi, United Arab Emirates.

Received: 22/06/15; accepted: 21/03/16 


\section{Introduction}

Waterpipe use is now the most prevalent form of tobacco use among young people in the Middle East with 9\%-16\% of school-age students reporting current waterpipe use $(1,2)$. A similar trend is found in Western nations $(2,3)$. Waterpipe users are exposed to the same carcinogens and nicotine as cigarette users, and exposure to carbon monoxide exceeds levels seen with cigarettes $(4,5)$. Waterpipe use is associated with the same smoking-related diseases and more than doubles the risk of lung cancer $(6,7)$. Tobacco use surveillance data indicates rapid growth in waterpipe use, both in the Middle East and internationally. In Jordan, waterpipe use increased by $86 \%$ among students between 2008 and 2011 (8). Data from the California Tobacco Survey showed waterpipe use increased by more than 40\% between 2005 and 2008 (9).

Given the growth in prevalence and health risks, waterpipe control efforts are needed. The United States Food and Drug Administration does not regulate waterpipe tobacco composition, labelling or advertising. Even though current policies, such as the Clean Indoor Air Act (CIAA), appear to apply to waterpipe smoking, the language is not explicit, leaving legal avenues to claim exemption (10). To avoid falling under existing CIAA regulations, US waterpipe business owners classify their business as retail tobacco shops, claiming waterpipe is their primary activity, with the sales of food and alcohol considered incidental. A 2012 study of the 100 largest US cities found 73 banned cigarette use within bars but 63 provided exemptions allowing waterpipe use (11).

For the purpose of our study, waterpipe business refers to any organization that sells ready-to-use waterpipes in addition to other goods or services. Operator refers to the controlling owner or senior employee running the waterpipe business. Patron or customer refers to a person who buys any goods or services at the waterpipe business. Synonyms for waterpipe include hookah, shisha, and nargilah.

The growth in waterpipe use is creating calls for improved control by applying the same regulatory strategies proven successful with cigarettes: increasing the tax on pipe tobacco, applying warning labels to waterpipe tobacco, and banning flavoured tobacco in waterpipes $(8,9,12)$. While the experience of regulating cigarettes will inform the effort to control waterpipe use, important differences may exist between waterpipes and cigarettes that may complicate regulation (13). Waterpipe use is frequently a social event occurring with friends or family at retail businesses. The rise of the waterpipe epidemic has closely tracked the rise of both flavoured waterpipe tobacco and the growth of café culture in urban areas $(2,8,9)$. Little is known about these businesses supplying ready-to-use waterpipes to consumers. We evaluated the customers, operations, products and advertising of these businesses to explore the unique policy challenges created by the suppliers of waterpipes.

\section{Methods}

\section{Study population and sampling}

We completed a cross-sectional survey consisting of structured site observations and in-person interviews. Participants were a random sample of businesses offering ready-to-use waterpipes identified through internet searches using Google, Yelp, Timeout Dubai, and Timeout Abu Dhabi. Businesses with no online presence were also approached when discovered during site visits. To be included in the study, the business must have provided ready-to-use hookah on site. Interviews were conducted with the senior business operator present at the time of the interview, with preference given to owners or managers. The participants had to speak either English or Arabic and had to be 21 years or older.

All Internet searches generating a list of eligible businesses were completed in December 2013. The search terms hookah, waterpipe and shisha generated 130 unique businesses in Dubai, 69 in Abu Dhabi and 121 in New York City. A total of 29 businesses in Dubai, 28 in Abu Dhabi and 47 in New York City were randomly selected and approached for interview. During neighbourhood site visits, 9 additional Dubai, 13 Abu Dhabi, and 6 New York City businesses without an internet presence were located and approached. In all, 132 businesses were approached with observational data collected at 111 (84\%) businesses and in-person surveys completed at 97 (response rate of $73 \%$ ). The survey response rate of $60 \%$ in New York City was lower than in either Emirati city. Closed businesses most often prevented collection of observational data. Operators who declined to participate in the survey most commonly reported being too busy.

All site visits and interviews were completed between 9 January and 14 March 2014. Responses were recorded in Qualtrics software. A translator was used as needed in the United Arab Emirates (UAE) to read questions to the participant and translate responses back into English (Translators had a structured script to follow at each visit to maximize uniformity). Survey interviews were conducted only at consenting businesses. Institutional Review Board approval was obtained from $\mathrm{New}$ York University Medical Center and NYU Abu Dhabi Public Health Research Center.

\section{Study measures}

Observational survey data consisted of information publicly available to all patrons of the business. The presence or absence of specific menu categories was noted including: food, drinks and flavoured waterpipe tobacco. The presence of outdoor seating was 
documented. The main business activity observed at the time of the visit was identified as being waterpipe, food or drinks. Additionally, we noted whether any age restriction or waterpipe-specific discounts (e.g. buy one get another bowl free, "Happy hour" price reductions or free added flavours) were posted at the establishment.

Interviews consisted of questions for the respondent on age, type of position at the establishment, number of years employed at the business and whether the respondent had used a waterpipe within the last month. Questions on customer profile assessed age, percentage of female customers and percentage of customers who were regulars at the business. Basic business characteristics included whether the business was part of a franchise or chain, the number of employees and the year the business opened.

Questions on operations assessed what percentage of sales was attributable to waterpipe, the average number of waterpipes sold per day, and the cost to use one waterpipe. The question on cost represented the cost to get a waterpipe without extras such as blended flavours or special devices. All costs in the UAE were converted to US dollars based on an exchange rate of $\$ 1=3.67$ dirhams. Questions on waterpipe products assessed what percentage of waterpipe sales were for flavoured tobacco. Questions on marketing and promotional strategies assessed whether waterpipe discounts were offered to customers, whether the business used advertising (both traditional media and internet) and whether the business used Facebook specifically. Finally, a question assessing perceived levels of regulatory adherence was used, which was adapted from the World Bank's Enterprise survey (14). The survey tools and definition of terms are given in the Appendix, which is available on line at http://www.emro.who.int/emhjournal/eastern-mediterranean-healthjournal/home.html.

\section{Data analysis}

We analysed the data using SPSS statistical software and compared data on operator demographics by location. We compared all other data by location and whether the business was part of a franchise/chain. We used listwise deletion in the case of missing data. The percentage of missing variables were low for all observational (0\%-10.8\%) and survey $(1.0 \%-10.3 \%)$ variables. We analysed categorical variables using Pearson chi-squared or Fisher exact test and continuous variables using either one-way ANOVA or independent $t$ test. Nonparametric methods did not change determinations of significance for the continuous data.

\section{Results}

\section{Respondent characteristics}

Operators reported a mean age of 34.3 (95\% CI 32.9-35.8) years and had been working at their business for average of $3.5(2.7-4.3)$ years (Table 1). Managers were the most common position interviewed (77\%) with owners making up a smaller portion (11\%) of respondents.

\section{Customer profile}

Customers were most frequently (61\%) reported to be between the ages of 20 and 29 years. Customers were older in Dubai, where ages 30-49 years were reported to make up 57\% of patrons (Table 2). Only one business in Abu Dhabi reported a majority of its customers were under the age of 20 years. Women were well represented making up a mean of $42.5 \%$ (95\% CI: $39.1-45.9 \%)$ of customers. Regular or returning customers were reported to make up a majority of $59.4 \%$ (95\% CI: 54.4-64.4\%) of all customers.

\section{Business characteristics}

The average business opened in 2007 (2006, 2009). Businesses in Abu Dhabi were an average of 4 years older (Table 2) compared to the other cities $(f=5.0$, $P=0.01)$. Businesses had a mean of 25.6 full-time employees (19.2-32.0) with New York City businesses employing a smaller number of full-time employees (7.2, CI 2.5-11.9) than ones in Abu Dhabi (33.1, 95\% CI: 18.2-47.9) and Dubai (32.0, 95\% CI: 26.1-37.8; $f=$ 7.1, $P=0.001)$. However, New York City businesses averaged 5.3 part-time employees (95\% CI: 1.4-9.2), and Abu Dhabi and Dubai businesses reported

\begin{tabular}{|c|c|c|c|c|c|c|c|c|}
\hline \multirow[t]{2}{*}{ Location } & \multirow[t]{2}{*}{$n$} & \multicolumn{4}{|c|}{ Position [No. (\%)] } & \multirow{2}{*}{$\begin{array}{l}\text { Mean years in } \\
\text { position }\end{array}$} & \multirow{2}{*}{$\begin{array}{l}\text { Mean age } \\
\text { (years) }\end{array}$} & \multirow{2}{*}{$\begin{array}{c}\text { Waterpipe } \\
\text { smoking status (\%) }\end{array}$} \\
\hline & & Owner & $\begin{array}{l}\text { Manager/ } \\
\text { supervisor }\end{array}$ & $\begin{array}{l}\text { Waiter/ } \\
\text { Bartender }\end{array}$ & Other & & & \\
\hline Dubai & 32 & $2(6)$ & $25(78)$ & $1(3)$ & $4(13)$ & $3.2^{\mathrm{a}}$ & 34.2 & $16(50)^{b}$ \\
\hline Abu Dhabi & 33 & $3(9)$ & $29(88)$ & $0(0)$ & $1(3)$ & $4.8^{\mathrm{a}}$ & 34.5 & $12(38)^{b}$ \\
\hline New York City & 32 & $6(19)$ & $21(66)$ & $4(13)$ & $1(3)$ & $2.4^{\mathrm{a}}$ & 34.3 & $23(77)^{\mathrm{b}}$ \\
\hline All & 97 & $11(11)$ & $75(77)$ & $5(5)$ & $6(6)$ & 3.5 & 34.3 & $51(54)$ \\
\hline
\end{tabular}

${ }^{a}$ One way ANOVA $P=0.04$.

${ }^{b}$ Pearson chi-squared $P=0.007$.

c\% of operators using waterpipe in the past 30 days. 


\begin{tabular}{lccccc}
\hline Table 2 Waterpipe business type, products, and pricing by location & & & \\
\hline Variable & $n$ & Dubai & Abu Dhabi & New York City & All \\
Business type & & & & & \\
$\quad$ Franchise/chain [(\%. (no.)] & 96 & $16(52)^{\mathrm{a}}$ & $10(30)^{\mathrm{a}}$ & $2(6)^{\mathrm{a}}$ & $28(29)$ \\
$\quad$ Independent [(\%. (no.)] & 96 & $15(48)^{\mathrm{a}}$ & $23(70)^{\mathrm{a}}$ & $30(94)^{\mathrm{a}}$ & $68(71)$ \\
Mean year opened & 96 & $2009^{\mathrm{b}}$ & $2005^{\mathrm{b}}$ & $2009^{\mathrm{b}}$ & 2007 \\
Mean \% of sales waterpipe & 89 & 30.0 & 41.6 & 44.4 & 38.5 \\
Main business activity & & & & \\
$\quad$ Waterpipe [(\%. (no.)] & 110 & $5(15)^{\mathrm{a}}$ & $16(41)^{\mathrm{a}}$ & $22(58)^{\mathrm{a}}$ & $43(39)$ \\
$\quad$ Food [(\%. (no.)] & 110 & $28(85)^{\mathrm{a}}$ & $23(59)^{\mathrm{a}}$ & $10(26)^{\mathrm{a}}$ & $61(56)$ \\
$\quad 110$ & $0(0)^{\mathrm{a}}$ & $0(0)^{\mathrm{a}}$ & $6(16)^{\mathrm{a}}$ & $6(6)$ \\
$\quad$ Drinks [(\%. (no.)] & 111 & $34(100)^{\mathrm{c}}$ & $33(85)^{\mathrm{c}}$ & $29(76)^{\mathrm{c}}$ & $96(87)$ \\
Meod menu [(\%. (no.)] & 93 & $93.1^{\mathrm{d}}$ & $91.9^{\mathrm{d}}$ & $98.6^{\mathrm{d}}$ & 94.4 \\
Flavored tobacco menu (\%) & 106 & $31(100)$ & $36(97)$ & $38(100)$ & $105(99)$ \\
Mean price per pipe in US dollars & 95 & $12.94^{\mathrm{e}}$ & $9.69^{\mathrm{e}}$ & $21.08^{\mathrm{e}}$ & 14.50 \\
\hline
\end{tabular}

${ }^{a}$ Pearson chi-squared $P<0.001 .{ }^{b}$ One-way ANOVA $P=0.009$. ${ }^{c}$ Pearson chi-squared $P=0.01 .{ }^{d}$ One-way ANOVA $P=0.012 .{ }^{e}$ One-way ANOVA $P<0.001$.

no part-time employees. The majority of businesses surveyed were independent businesses, as franchises or chains made up only $28 \%$ of businesses over all three locations. Dubai was an exception, as franchises made up a majority of the market, accounting for 52\% of businesses. In New York City only 6\% businesses were franchises.

\section{Business operations}

Businesses reported 38.5\% (33.4-43.7) of sales were attributable to waterpipe. Observational data identified 39\% of businesses as primarily selling waterpipe and $56 \%$ primarily selling food. More New York City businesses (Table 2) were waterpipe-dominant (58\%), and food was the dominant generator of sales in Dubai (85\%). A majority of $87.0 \%$ businesses offered food in addition to waterpipe within their menu. Food was listed in every franchise menu while only $82 \%$ of independent businesses listed food $(P=0.02)$. Offering outdoor seating was common (62\%) among businesses. Businesses reported selling a mean of 74.7 (95\% CI: 59.5-90.0) pipes per day. The average cost in US dollars to smoke one waterpipe bowl was US\$ 14.50 (95\% CI: 12.89-16.11). The cost of one bowl was higher in New York City at US\$
21.08 (95\% CI: 16.20-79.3) and lower in Abu Dhabi at US\$ 9.69 (95\% CI: $7.60-11.77 ; f=26.7, P<0.001)$.

\section{Products and sales}

Flavoured tobacco sales made up over $90 \%$ of sales in all cities as businesses reported 94.4\% (95\% CI: 92.5-96.5\%) of sales were flavoured. In New York City, nearly the entire market consisted of flavoured waterpipe tobacco (Table 2), while in the UAE traditional salloum tobacco made up a minority of sales. All but one the Abu Dhabi businesses offered flavoured tobacco within their menu.

\section{Promotion}

Waterpipe specials or discounts (Table 3) were reported by $47 \%$ of businesses, and $32 \%$ had waterpipe discounts on display during site visits. Both reported and observed waterpipe discounts were more prevalent at independent establishments (56\% and 43\% respectively) compared to franchises or chains (22\% and $13 \% ; P=0.003$ and $P=0.008$ ). Nearly all businesses (94\%) reported using at least some form of advertising. A Facebook presence was reported by $64 \%$ of businesses, with Facebook use being more common in Dubai and New York City $(P=0.007)$. A website was listed on the menu of $32 \%$ of businesses visited.

\section{Regulation and adherence}

A minority of $12 \%$ of businesses surveyed reported knowledge of competing against unregistered or informal firms. Age restrictions were posted, inside or outside the establishment, at $16 \%$ of businesses. Age restrictions were more frequently posted (32\%) in New York City.

\section{Discussion}

To our knowledge, this study is the first to describe the businesses providing ready-to-use waterpipes to customers in urban areas. These waterpipe businesses contribute to the epidemic by promoting waterpipe use via traditional and social media advertising and by pairing waterpipe with food, drinks, or other goods or services. This study identifies tobacco control challenges unique to waterpipe use.

Consistent with previous research, customers at waterpipe service businesses were commonly young adult males, with women well represented (15). Given the limitations of operator reported data, further research is needed to determine how the demographics of waterpipe business patrons differ from the general waterpipe-smoking population. Only one business reported 


\begin{tabular}{|c|c|c|c|c|c|c|c|c|c|}
\hline \multirow[t]{2}{*}{ Variable } & \multicolumn{4}{|c|}{ Location } & \multicolumn{5}{|c|}{ Business type } \\
\hline & $n$ & Dubai & Abu Dhabi & $\begin{array}{l}\text { New York } \\
\text { City }\end{array}$ & Total/all & $n$ & Independent & $\begin{array}{l}\text { Franchise/ } \\
\text { chain }\end{array}$ & $\begin{array}{c}\text { Total/ } \\
\text { all }\end{array}$ \\
\hline $\begin{array}{l}\text { Reported discount } \\
{[(\% . \text { (no.)] }}\end{array}$ & 94 & $15(48)$ & $12(36)$ & $17(57)$ & $44(47)$ & 93 & $37(56)^{e}$ & $6(22)^{e}$ & $43(46)$ \\
\hline $\begin{array}{l}\text { Posted discount } \\
{[(\% . \text { (no.) }]}\end{array}$ & 99 & $9(32)$ & 7 (19) & $16(46)$ & $32(32)$ & 85 & $26(43)^{f}$ & $3(13)^{f}$ & $29(34)$ \\
\hline $\begin{array}{l}\text { All advertising } \\
{[(\% . \text { (no.)] }}\end{array}$ & 87 & $32(100)^{a}$ & $24(83)^{\mathrm{a}}$ & $26(100)^{\mathrm{a}}$ & $82(94)$ & 86 & $53(91)$ & $28(100)$ & $81(94)$ \\
\hline Facebook [(\%. (no.)] & 87 & $24(75)^{b}$ & $12(41)^{b}$ & $20(77)^{b}$ & $56(64)$ & 86 & $36(62)$ & $19(68)$ & $55(64)$ \\
\hline $\begin{array}{l}\text { Website on menu } \\
{[(\% . \text { (no.) }]}\end{array}$ & 103 & $18(58)^{\mathrm{c}}$ & $7(19)^{c}$ & $6(17)^{c}$ & $31(30)$ & 85 & $14(23)^{g}$ & $13(54)^{g}$ & $27(32)$ \\
\hline $\begin{array}{l}\text { Posted age restriction } \\
{[(\% \text { (no.)] }}\end{array}$ & 111 & $4(12)^{d}$ & $2(5)^{d}$ & $12(32)^{d}$ & $18(16)$ & 91 & $13(20)$ & $2(8)$ & $15(17)$ \\
\hline
\end{tabular}

${ }^{a}$ Pearson chi-squared $P=0.005 .{ }^{b}$ Pearson chi-squared $P=0.007 .{ }^{c}$ Pearson chi-squared $P<0.001 .{ }^{d}$ Pearson chi-squared $P=0.005$. ${ }^{e}$ Pearson chi-squared $P=0.003 .{ }^{f}$ Pearson chi-squared $P=0.008 .{ }^{g}$ Pearson chi-squared $P=0.005$.

serving clientele below the age of 20; however, fear of admitting regulatory nonadherence makes under-reporting likely. Repeat customers represent a large portion of patrons and these customers may be at higher risk of addiction to waterpipe tobacco. The results show these businesses are not simply catering to novice or occasional users, and the profitability of their business model may be dependent on repeat customers at greatest risk of addiction. This finding also raises the question of how often an addiction to waterpipe is maintained with little or no home waterpipe use.

Businesses in Abu Dhabi were older, suggesting this market predates the relatively new market in Dubai and the more recent growth in waterpipe popularity in New York City. Independent businesses make up the majority of the market in the urban areas sampled, with Dubai being the exception as franchises made up a slight majority. Given the cross-sectional nature of this study, we cannot suggest how these markets are evolving but waterpipe franchises in a global city like Dubai, with growing global demand for waterpipe use, may seek to expand into further markets.

Our study suggests waterpipe sales are actually a minority of revenue for businesses offering waterpipes, with food being the dominant sales item at the majority of businesses. This finding is consistent with a survey of 144 US waterpipe café websites showing $79 \%$ of establishments served food (16). Franchises and chains always offered food, and this suggests a strategy of diversifying sales beyond waterpipes. With this business model being common, some customers may enter an establishment with the intent of purchasing food only to end up also using waterpipe. For businesses offering food and other sales items, it remains unclear if they will be less resistant to waterpipe regulation. A majority of New York City businesses offered food, and to our knowledge this provides the first direct evidence that many of these businesses may not actually be eligible for exemption from clean air regulations as a tobacco retail establishment as has been previous suggested (11).

The average price of a standard waterpipe bowl was not prohibitive of dailyuse, especially if cost is shared within a group. This finding supports the recommended tax increase on waterpipe tobacco (12). However, the price elasticity of waterpipe use remains unclear as prevalence may be highest among affluent youth, and changes in price may simply shift café users to their homes (17).
Consistent with studies of waterpipe users, both operator-reported and direct menu observations, show the market is nearly completely dominated by flavoured tobacco. These data further show flavoured tobacco plays a central role in the waterpipe epidemic (2). The pervasiveness of flavoured waterpipe tobacco suggests that banning flavours would affect nearly every waterpipe business and would likely be met with industry resistance.

The urban businesses we surveyed were actively engaged in promoting their business and waterpipe use, with nearly all businesses reporting some active advertising strategy and nearly half using waterpipe-specific discounts to attract customers. The high reported use of Facebook paired with the listing of promotional websites within the menu further supports the role social media are playing in the growth of waterpipe smoking (2). Overall locally driven promotions by small independent businesses may be contributing to rising demand for waterpipes. This raises difficult questions about the ability to regulate social media advertising and whether bans on waterpipe-specific discounts are needed if any priced-based control method is to be employed. For cigarettes, increased price through taxation has been one of the most effective 
tobacco control measures, and elimination of discounts has been necessary to avoid industry efforts to mitigate the effect of taxation.

Only a small portion of businesses sampled reported knowledge of regulatory nonadherence among competitors; however this question is likely to be subject to under-reporting. We did not ask directly about compliance with current regulations given the respondents' likely fear of incrimination. The small portion of businesses with a posted age restriction suggests that underage access needs greater regulatory and enforcement scrutiny.

Our study suggests several regulatory challenges that are unique to waterpipe. First, the effectiveness of prohibiting traditional advertising of waterpipes may be reduced because waterpipe businesses use social media and can fall back on promoting other goods and services to attract customers. Second, if taxation of pipe tobacco is implemented to reduce levels of waterpipe use, prohibitions of waterpipe discounts will be needed. However, businesses can still compensate for these restrictions by offering promotional discounts on alternative goods or services. Third, the banning of flavoured pipe tobacco could be effective in reducing levels of waterpipe use, but this study makes clear that flavoured pipe tobacco is almost universally used among businesses. Such a policy would be met with resistance and would prohibit waterpipe use as the market is currently composed. Finally, if age restrictions are to have an impact, then better enforcement mechanisms are needed and simple postings are insufficient.

\section{Limitations}

Our initial sampling frame required businesses to have an online presence. While subsequent neighbourhood sampling reached businesses with no online presence, our sample may not be representative of businesses without an online presence. The small sample size limited the statistical power of the study. It is important to place the findings of this study within the context of the unique metropolitan cities where the data was collected. We have attempted to focus on measures and indicators relevant across urban markets but this sample may not be representative of the global urban waterpipe business market. It is also important to note some of the data collected for this study was operator-reported, such as the customer demographic data, and managers and owners may provide incomplete or incorrect information. While comments provided by business operators did often reveal sensitive information, some findings may be under-reported/ unreported due to regulatory or competitive pressures.

\section{Conclusion}

The prevalence of waterpipe use is growing worldwide, with waterpipe businesses playing an important role in the epidemic. This study shows that the waterpipe café market is largely made up of independent businesses, with a large regular customer base, frequently offering diversified services beyond waterpipes, and these businesses use both traditional media and social media for promotional purposes. The centrality of these businesses to the waterpipe epidemic distinguishes it from economics and behaviour of cigarette consumption and suggests that unique regulatory challenges will have to be addressed in order to adequately control this epidemic. Successful cigarette control strategies, such as advertising restrictions, price controls, product or age restrictions, will need adaptation to the unique realities of the waterpipe business market.

\section{Acknowledgements}

The authors would like to thank Abdishakur Abdulle, $\mathrm{PhD}$ and Maryse Bibeau for their help in organizing and conducting the field research in the United Arab Emirates. SS devised the study. PJ, STS, LP, MBW, and SS were responsible for planning the study and for data collection. MBW was responsible for preparation of the data for data analysis. PJ was responsible for data analysis. PJ drafted and revised the paper. All authors approved the final manuscript. No financial disclosures were reported by the authors of this paper.

Funding: This project was supported by the New York University Global Institute of Public Health (which is now the NYU College of Global Public Health) and the NYU/Abu Dhabi Public Health Research Center. None of the authors have any further funding sources or affiliations to disclose. The study sponsor had no role in study design; collection, analysis, and interpretation of data; writing the report; and the decision to submit the report for publication.

Competing interests: None declared.

\section{References}

1. Akl EA, Gunukula SK, Aleem S, Obeid R, Jaoude PA, Honeine $\mathrm{R}$, et al. The prevalence of waterpipe tobacco smoking among the general and specific populations: a systematic review. BMC Public Health. 201104 19;11(1):244. PMID:21504559

2. Maziak W, Taleb ZB, Bahelah R, Islam F, Jaber R, Auf R, et al. The global epidemiology of waterpipe smoking. Tob Control. 2015 Mar;24 Suppl 1:i3-i12. PMID:25298368
3. Johnston LD, O'Malley PM, Bachman JG, Schulenberg JE. Teen smoking continues to decline in 2013. Ann Arbor: Institute for Social Research, The University of Michigan; 2013.

4. St Helen G, Benowitz NL, Dains KM, Havel C, Peng M, Jacob P 3rd. Nicotine and carcinogen exposure after water pipe smoking in hookah bars. Cancer Epidemiol Biomarkers Prev. 2014 Jun;23(6):1055-66. PMID:24836469 
5. Martinasek MP, Ward KD, Calvanese AV. Change in carbon monoxide exposure among waterpipe bar patrons. Nicotine Tob Res. 2014 Jul;16(7):1014-9. PMID:24642592

6. Akl EA, Gaddam S, Gunukula SK, Honeine R, Jaoude PA, Irani J. The effects of waterpipe tobacco smoking on health outcomes: a systematic review. Int J Epidemiol. 2010 Jun;39(3):834-57. PMID:20207606

7. Maziak W. The waterpipe: an emerging global risk for cancer. Cancer Epidemiol. 2013 Feb;37(1):1-4. PMID:23196170

8. McKelvey KL, Wilcox ML, Madhivanan P, Mzayek F, Khader YS, Maziak W. Time trends of cigarette and waterpipe smoking among a cohort of school children in Irbid, Jordan, 2008-11. Eur J Public Health. 2013 Oct;23(5):862-7. PMID:24078649

9. Smith JR, Edland SD, Novotny TE, Hofstetter CR, White MM, Lindsay SP, et al. Increasing hookah use in California. Am J Public Health. 2011 Oct;101(10):1876-9. PMID:21852640

10. Noonan D. Exemptions for hookah bars in clean indoor air legislation: a public health concern. Public Health Nurs. 2010 Jan-Feb;27(1):49-53. PMID:20055968

11. Primack BA, Hopkins M, Hallett C, Carroll MV, Zeller M, Dachille $\mathrm{K}$, et al. US health policy related to hookah to- bacco smoking. Am J Public Health. 2012 Sep;102(9):e47-51. PMID:22827447

12. Morris DS, Fiala SC, Pawlak R. Peer Reviewed: Opportunities for Policy Interventions to Reduce Youth Hookah Smoking in the United States. Prev Chronic Dis. 2012;9:E165. PMID:23153772.

13. Maziak W, Nakkash R, Bahelah R, Husseini A, Fanous N, Eissenberg T. Tobacco in the Arab world: old and new epidemics amidst policy paralysis. Health Policy Plan. 2014 Sep;29(6):784-94

14. The World Bank. Enterprise Survey. 2013 (http://www.enterprisesurveys.org/, accessed 1 May 2016).

15. Maziak W. The waterpipe: a new way of hooking youth on tobacco. Am J Addict. 2014Mar-Apr;23(2):103-7.PMID:25187045

16. Primack BA, Rice KR, Shensa A, Carroll MV, DePenna EJ, Nakkash R, et al. U.S. hookah tobacco smoking establishments advertised on the internet. Am J Prev Med. 2012 Feb;42(2):150-6. PMID:22261211

17. PalamarJJ,ZhouS, ShermanS, Weitzman M. Hookah use among U.S. high school seniors. Pediatrics. 2014 Aug;134(2):227-34. PMID:25002664 